\title{
Adaptive Physical Education Model for Increasing Physical Fitness of Children With Intellectual Disability
}

\author{
Euis Heryati, Een Ratnengsih
}

Universitas Pendidikan Indonesia, Bandung, Indonesia

e-mail: euis heryati@upi.edu

\begin{abstract}
Children with intellectual disability have a weakness of motor skills, they tend to be less active. Minimal activity plays a major role in increasing the risk of overweight and obesity in children with intellectual disability. Overweight and obesity in children may increase the risk of various health problems and affect physical fitness. So this will worsen the physical abilities of children especially in mobility. Adaptive physical education is one of alternative way to solve the problems. This study aims to develop design model of adaptive physical education to increase physical fitness and descrease weight of children with intellectual disability. This study is one step of research development. This study through the preliminary stage, the initial model design and validation test by experts through discussion and suggestions written analyzed descriptively. The results of research are : a) physical fitness profile of children with intellectual disability are low and very low level, while body mass index (BMI) of the children is in the range 28-38 so categorized obesity level I and level II, b) the implementation of adaptive physical education in the school found many obstacles, so that the implementation is not optimal; c) design model of adaptive physical education consist of: assessment, determination of the program, implementation program, evaluation, and supporting factor.
\end{abstract}

Keywords: $\quad$ adaptive physical education, physical fitness, children with intellectual disability

\section{INTRODUCTION}

Overweight and obesity are excess nutrient problems that are increasingly found in children around the world. Overweight and obesity in children are a consequence of higher calories (energy) received than the amount of calories released or burned through metabolic processes in the body.

A minimum activity pattern plays a major role in increasing the risk of overweight and obesity in children. Overweight and obesity are more easily suffered by children who lack of physical activity or sport, which is due to the less number of calories burned than calories received and potentially cause the accumulation of fat in the body.

Children with Special Needs (CSN), particularly children with intellectual disabilities, tend to move a bit or lack of activity, so it will pose a greater risk for obesity. Children with intellectual disabilities are known to have a weakness in terms of motor skills, less healthy in physical condition, motor coordination, lack of confidence about the situation and the circumstances around it, less finemotor and grossmotor skills (Delphie B, 2006).

One aspect that is very important and has an influence on the motoric physical capabilities is fitness and obesity problem factor. According to data obtained by the CDC in 2010, in Laura (2011), as much as $20 \%$ of children with disabilities between the ages of 10 to 17 years suffer from obesity while children of the same age without physical or mental disability suffer from obese of only $15 \%$.

Results of a research conducted by Putra (2014) on children with hearing impairment and intellectual disabilities stated that the nutritional status of children with intellectual disabilities according to $\mathrm{BMI} / \mathrm{U}$ index represents as much as $16.1 \%$ were classified as underweight, and as many as $24.2 \%$ classified as obese. Based on the nutritional status of the subjects according to TB/U indexes, as much as $16.1 \%$ were classified as short. Based on the nutritional status of the subjects according to the $\mathrm{BMI} / \mathrm{U}$ and $\mathrm{TB} / \mathrm{U}$ index, as much as $6.5 \%$ were classified as thin and short, and as much as $4.8 \%$ were classified as obese and short. Group of 
disability subjects with highest obese nutritional status in intellectual disabilities group is 12 children (54.5\%). Meanwhile, the highest underweight nutritional status in hearing impairment group is 8 children $(20.0 \%)$.

Children with intellectual disability tend to be more overweight, while the children with hearing impairment tend to be more underweight. This situation resulted from a level of activity of intellectually disabled children which is less than those children with hearing impairment. The intellectually disabled children require help from others to assist them in conducting activities than children with hearing impairment who have a deficiency only in terms of hearing.

Other studies have also found that children with intellectual disabilities mostly suffer from obesity than children with hearing impairment, this is because the general characteristics of intellectually disabled children who are prefer to eat more, as well as less moving habit, while children with hearing impairment tend to be thinner because their activities are more excessive than the food intake (Masashige, et al. 1991).

Therefore, an activity or physical activity is required as a form of treatment given to children with intellectual disabilities to help them improve fitness level and minimize overweight or obese problems. Later, it is expected that the children can easily perform all of their daily activities.

An adaptive physical education is a physical education adapted or modified to facilitate learners with special needs to participate actively in physical education subject in schools. Through adaptive physical education designed for children with intellectual disabilities, especially those with obesity, it is expected to increase active participation and physical activity in order to help in improving physical fitness and decrease obesity.

Conceptually, Herbert J. Prehm in Philp I. Browning (1974) stated that children with intellectual disabilities 1) is a condition, 2) are those with mental condition that is far below the average, 3) have obstacles in social adjustment, 4) have organic damage to the central nervous system, and 5) cannot be cured. Therefore, from these criteria, American Association on Mental Retardation (AAMR) describes mental retardation as demonstrating the limitations in intellectual functioning that is below average, and the limitations in two or more adaptive skills such as communication, self-care, social skills, health and security, academic functioning, leisure, etc. This situation appears before the age of 18 years (Suharmini, 2007: 67).

Barriers faced by children with intellectual disabilities are quite a lot, which is caused by the low development of the intelligence function and low adaptive behavior that also resulted an obstruction in their daily activities. According Alimin (2003), barriers of children with intellectual disabilities include: learning problems, problems of adjustment to the environment, the issue of speech and language disorders, and personality. However, empirically, obstacles arise within intellectually disabled children will greatly vary in the terms of level depends on the weight or lightness of their level of disabilities.

Obesity means having excess weight or overweight, due to excess calorie intake which is not accompanied with excessive energy use. Currently, the prevalence of obesity in children and adolescents increased sharply worldwide. The prevalence in children aged 6-17 years in the United States of the last three decades has increased from 7.6 to $10.8 \%$ to $13-14 \%$. The prevalence of obesity in children of school age in Singapore increased from $9 \%$ to $19 \%$ (Utari A, 2007). A study conducted on children of school age in ten big cities in Indonesia in the period of 2002-2005 with a random method shows the prevalence of obesity in children of primary school age in order from the highest is Jakarta (25\%), Semarang (24.3\%), Medan (17.75\%), Denpasar (11.7\%), Surabaya (11.4\%), Padang (7.1\%), Manado $(5.3 \%)$, Yogyakarta $(4 \%)$, and Solo $(2.1 \%)$. The average prevalence of obesity in the ten cities reached 12.2\% (Revelation GG, 2009).

The phenomenon of the increasing overweight and obesity prevalence of children in Indonesia is very worrying. This happens due to the lack of public awareness in educating their children to live healthier by sufficiently meeting the daily fiber need, getting lots of activities and enough exercises, and avoiding foods that are high in calories, such as the fast food and so on.

One of the ways that can be used to measure overweight and obesity is by using the Body Mass Index (BMI). BMI measurement is done by dividing the weight $(\mathrm{kg})$ by the square of the height $(\mathrm{m})$. This value is then plotted on a growth curve of children, which is adapted to the sex and age of the child.

Physical fitness is a state owned or achieves in relation to the ability to perform the activity. Physical fitness is related to health as physical activity when it can be carried out without excessive fatigue, maintained lifetime and consequently have lower risk of early chronic disease (Nieman, D., 
2001, in Utari A., 2007). A person who is physically fit to perform daily physical activities has a low risk of health problems and can enjoy sports and other activities (Utari A 2007).

\section{METHODS}

The research approach used is a mixedmethod approach, while the type of research is development research. This study is the first phase of the overall development research design. The first phase of this study consists of: a preliminary study to see objective conditions on the level of obesity and physical fitness of children with intellectual disabilities and assess the processes or services in the form of adaptive physical education at school. The second is to formulate adaptive physical education models developed and to conduct expert validation test so that the draft of model from validation test result is acquired. Preliminary research conducted at the School for Exceptional C in Bandung, Indonesia.

\section{RESULTS AND DISCUSSION}

To obtain data on the objective conditions or profile of intellectually disabled children with obese in physical fitness, the researchers used a test and interview techniques. Data on physical fitness is important to be taken, because it enables the researchers to determine the level of physical fitness of intellectually disabled children with obesity. Moreover, other profiles related to viability, barriers and lifestyles associated with the obesity are discovered. Researchers observed four children with intellectual disabilities in SLB C YPLB Cipaganti.

The four children taken as the subject of information in this study were those who were declared as having obesity based on the results of identification.

Furthermore, anthropometric data collection is done by a measurement of height, weight and age of the child growth chart. The next data retrieval on various aspects of children physical fitness is done through a series of tests that refers to TKJI (Indonesia Physical Fitness Test), among others: pull-ups, sit-ups, vertical jump, fast running and moderate running. Other data retrieved is about viability, barriers and lifestyles associated with the obesity. Data were collected through interview techniques. The results of data collection on the subject of research can be seen in the following table:
Table 1. Body Mass Index (BMI) of Research Subjects

\begin{tabular}{|l|l|l|l|l|l|l|}
\hline No & Name & $\begin{array}{l}\text { Date of } \\
\text { birth/Age }\end{array}$ & $\begin{array}{l}\text { Height } \\
\mathbf{( m )}\end{array}$ & $\begin{array}{l}\text { Weight } \\
\mathbf{( k g})\end{array}$ & BMI & Category \\
\hline 1 & RO & $\begin{array}{l}04-03-2003 \\
1 / 3\end{array}$ & 151 & 72,9 & 31,97 & Obesity II \\
\hline 2 & ZH & $\begin{array}{l}23-10-2000 \\
115\end{array}$ & 144 & 79,8 & 38,48 & Obesity II \\
\hline 3 & RN & $\begin{array}{l}03-04-1999 \\
117\end{array}$ & 180 & 92,3 & 28,48 & Obesity I \\
\hline 4 & LH & $\begin{array}{l}09-08-1996 \\
19\end{array}$ & 164 & 87 & 32,35 & Obesity II \\
\hline
\end{tabular}

Table 2. Test Result of Research Subject Physical Fitness

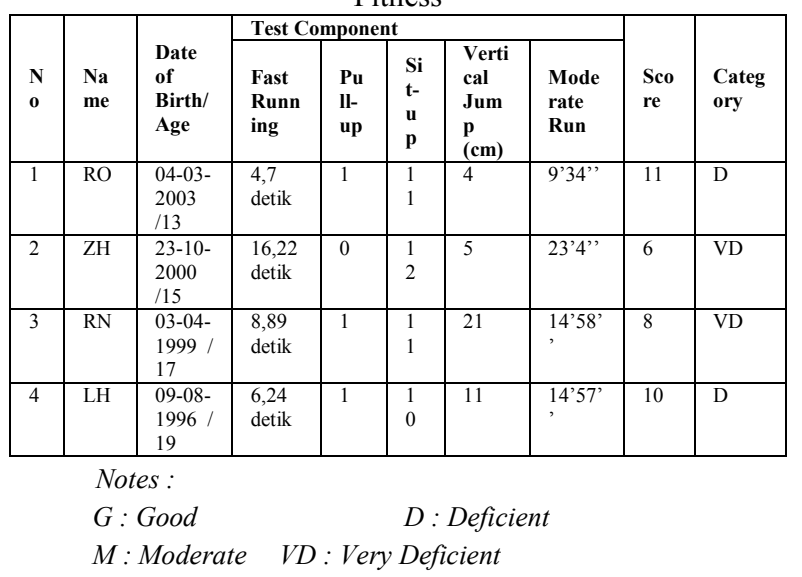

The data acquisition concerning the implementation of adaptive physical education in schools is as follows:

\section{Teacher's Understanding of Adaptive Physical Education}

Interview data on teachers' understanding of the adaptive physical education shows that almost all teachers are familiar with and know about it. Some teachers had attended training and seminars of adaptive physical education. In SPLB-C YPLB Cipaganti, there are teachers whose background majoring in sports. Therefore, the frequency of participation of seminars and training activities are more frequently attended by physical education teachers. Historically, principals and teachers explained that before the appearance of adaptive physical education program, the implementation physical education subjects have not been optimal. In addition, the condition of children is less influenced by the implementation of such sport. Over time, the implementation of adaptive physical education in schools raises the appeal as a comparative study and practice of adaptive physical education development from both inside and outside the country. Some countries once visited the school are Japan and the Netherlands.

The special characteristic of the implementation of adaptive physical education in schools is the impact of the learning objectives which is not only 
limited to the achievements in the curriculum. In detail, the teachers describe that the purpose of the adaptive physical education is divided into three; learning achievement, scholastic achievement and developmental aspects achievement. The most prominent development in adaptive physical education at this school is in scholastic achievement. Some students once participated in contests both in the city, provincial, national or international level. Some managed to win the contest.

There are steps undertaken by teachers in the implementation of adaptive physical education which begin with assessing, planning program in the form of lesson plans, implementation and evaluation.

\section{Preparation of Adaptive Physical Education Learning}

Getting started in a teaching and learning activity is an important aspect that should be there. In SPLBC YPLB Cipaganti, the preparation of adaptive physical education lesson starts from doing the assessment process of the children either on the general assessment of developmental and academic aspects or special assessment of adaptive physical education. The preparation of adaptive physical education learning at school is begun by creating a lesson plan that refers to the curriculum for the sake of administrative compliance. However, teachers also design individual learning program to suit each child's condition, including the methods and ways of evaluation. Teachers use individualized format of learning program designed by Dutch practitioners who have practiced adaptive physical education in this school. Teachers use these formats due to the practicality. The plan was compiled by physical education teachers in all levels and classes in the school.

There are supporting factors of the preparation of adaptive physical education learning at this school; first, the background of physical education teachers derived from sports science major; second, some teachers have received training of adaptive physical education; third, the facility available in schools is adequate. There are also several factors being barriers in planning adaptive physical education learning; that is not all teachers want to be involved in planning the adaptive learning. Therefore, the physical education teachers have to construct a plan for all classes and levels.

\section{The Implementation of Adaptive Physical Education Learning}

Before the implementation of learning is started, teacher searches for the child's ability through assessment; creates a program and prepares the tools that will be used for the implementation of adaptive physical education learning. Limited resources to the implementation of adaptive physical education learning in school have an impact on its technical implementation. Every child at certain educational level gets only one time adaptive physical education learning in one week. However, the school provides an opportunity for children to get adaptive physical education learning in extracurricular activities. At the middle and high school education, the implementation is often conducted simultaneously for the sake of effective implementation. Each child is possible to obtain an adjustment in the learning process of adaptive physical education, in accordance with the child's condition and the overall objective of this study.

The learning method used in the implementation of adaptive physical education is varied, but its implementation tends to be in the classical style. For certain children who are directed to the scholastic achievement, the implementation of adaptive physical education learning is done individually in accordance with the focus of physical education being studied.

The factor that supports the implementation of adaptive physical education learning is adequate facilities; by which the students' motivation in attending physical activities tends to be higher. As for the inhibiting factor is a less involvement of classroom teachers in the implementation of adaptive physical education learning; classroom teachers tend to leave the responsibility of implementing the learning to physical study teachers, while the number of physical study teachers in the schools is only one person.

\section{Evaluation of Adaptive Physical Education Learning}

The evaluation of adaptive physical education learning is carried out in accordance with the child's condition. Each child with different conditions will earn different achievements and evaluation. The evaluation is done periodically through formative tests as well as summative tests and evaluations in accordance with the child's condition. 
The formulation of adaptive physical education plan to increase physical fitness and lose weight of intellectually disabled children with obesity consists of several components, namely: (1) Assessment; (2) Program; (3) Implementation; (4) Evaluation; (5) Supporting Factor. The entire component is a series of integral and implemented in a sustainable manner. It is visualized as follows:

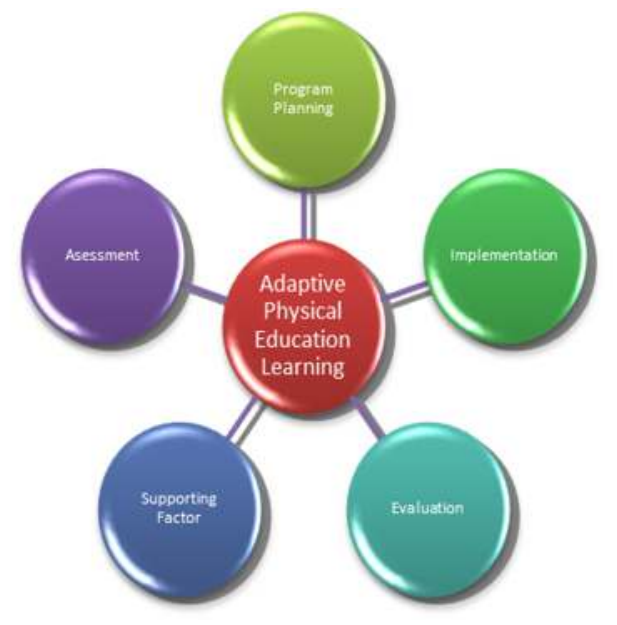

Figure 1. The Components of Adaptive Physical Education

The developed design model is a reference for the development activities of adaptive physical education learning model used to improve physical fitness and lose weight. The development is done by following the steps as follows: (1) Lesson Plan Draft. The activities undertaken in designing the lesson plan begins with the collection of data or information about the condition of children with intellectual disabilities. Furthermore, analysis is conducted with an aim to give an overview of what to consider in the components of learning. Adjustments or adaptations are conducted, especially in the formulation of objectives, materials, methods, and evaluation or assessment. (2) Implementation of the learning process. Implementation of the learning process is done in three settings, namely classroom (formal), extracurricular (informal) and family (informal) setting. (3) Evaluation, that is the assessment to the planning, the implementation and the impact of the implementation of learning. The detailed design of the adaptive physical education to increase physical fitness and lose weight of intellectually disabled children with obesity is as follows:

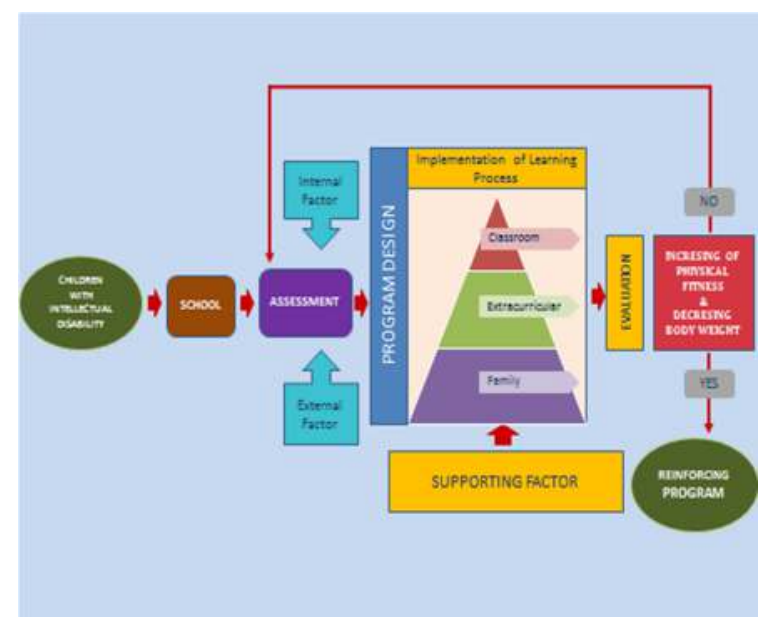

Figure 2. Adaptive Physical Education Model Design

Adaptive physical education model in its implementation should be based on several principles. The principles of adaptive physical education are generally used as guidelines, they are: the principle of individualization, learner-centered, based on the assessment results, maintain or improve fitness and physical health of students, fun and challenging, build character, charged with the aesthetic value and uphold moral values, encourage learners to actively construct knowledge independently, rehabilitative adaptive motion, accommodate corrective learning and improvement of physical and social development, attention to physical and psychological conditions of learners, encouraging physical education achievement if possible, functionally supporting daily life activities, activity-based context, apperception, motivation, cooperation, harmony with the environment and integrative. In particular, the principle that must be held in the development of adaptive physical education for intellectually disabled children with obesity is to involve the environment of the children, especially the family which has the largest percentage in the role and the highest frequency in affecting children. Besides, taking into account the other supporting factors that are not directly related but leave a significant impact on the success of the adaptive physical education program is important especially in addressing the problem of obesity and physical fitness. Other supporting factor mentioned here is related to the lifestyle (eating, activity, structure and physiological functions of the body, and others). 


\section{CONCLUSIONS}

So it can be concluded that:

1. The subjects of the research were four people; one female and three males. Three of them sustain level II obesity, while another one have level I obesity. The fitness levels of the subjects are on the category of D (Deficient) and VD (Very Deficient).

2. The description of the implementation of adaptive physical education learning is started with teacher's exploration on children's abilities through assessment, then constructing a program and preparing for tools that will be used in the teaching and learning process. However, limited resources impact on the technical implementation.

3. The constructed model is a hypothetic model and specifically tailored for the school, classroom teachers, physical education teachers, and medical teachers who handle intellectually disabled children with obesity. However, in the designed model, family/parents with intellectually disabled children often become the target that have to actively participate in adaptive physical education.

4. The components included in this hypothetic model comprise: assessment, programs, implementation, evaluation, and supporting factors.

\section{REFERENCES}

[1] Abduljabar, B. (2012). The Joy of Movement. Sebuah Laporan Kerjasama FPOK UPI dengan Calo-Windesheim University the Netherland. Bandung. Rizqi Press.

[2] Alimin, Z \& Rochyadi, E. (2003). Pengembangan Program Pembelajaran Individual bagi Anak Tunagrahita. Jakarta Direktorat Pendidikan Tinggi Departemen Pendidikan Nasional.

[3] Auxter, D. et.al. (2001). Principles and Methods of Adapted Physical Education and Recreation. New York. Mc Graw Hill Companies.

[4] Bandi, D. (2006) Pembelajaran Anak Tunagrahita. Bandung : Refika Aditama

[5] Bandi, D. (2009) Pembelajaran Anak Berkebutuhan Khusus Dalam Setting Pendidikan Inkluasi, Sleman: KTSP

[6] Dirjen Pendidikan Dasar Kementerian Pendidikan dan Kebudayaan. (2013) Pedoman Penyelenggaraan Program Pendidikan
Jasmani Adptif Bagi Peserta Didik Berkebutuhan Khusus di Sekolah inklusi. Jakarta

[7] Masashige S., Shinichi S., Yousuke T, Yoshiharu S., Ritsuko M., \& Norimasa H. (1991). Nutritional Status and Daily Physical Activity Of Handicapped Students In Tokyo Metropolitan Schools For Deaf, Blind, Mentally Retarded, And Physically Handicapped Individuals. The American Journal of Clinical Nutrition, Vol. 54 :01-11.

[8] Sahati, T. 1997. Hubungan persen Lemak Tubuh dengan Kesegaran Jasmani menurut tes ACSPFT pada anak usia 6-12 tahun di 10 sekolah dasar di DKI Jakarta. Tesis. Universitas Indonesia Jakarta.

[9] Strecker,L.E. (2011). School Nutrition: Addressing Obesity Among Children with Disabilities. ProQuest Research Library, 25, 26-28.

[10] Sugaama, P.K \& Tresna, A.K. (2014). Status Gizi Penyandang Cacat (Tunagrahita Dan Tunarungu) Di Sekolah Luar Biasa B Negeri Pembina Tingkat Nasional Kelurahan Jimbaran Kabupaten Badung. Jurnal Community Health, Vol. II No 1 Januari 2014

[11] Tin, S. (2007). Psikologi Anak Berkebutuhan Khusus. Departemen Pendidikan Nasional Direktorat Jenderal Pendidikan Tinggi Direktorat Ketenagaan.

[12] Tarigan, B. 2008. Modul Pendidikan Jasmani Adaptif. FPOK Universitas Pendidikan Indonesia, Bandung

[13] Utari, A. 2007. Hubungan Indeks Massa Tubuh dengan Tingkat Kesegaran Jasmani pada Anak Usia 12-14 Tahun. Tesis. FK Universitas Dipenogoro Semarang.

[14] UNJ dan Direktorat PKLK Dikdas Kemendikbud (2014) Pedoman Pembelajaran Pendidikan Jasmani Adaptif bagi Peserta Didik Autis di SMPLB, jakarta:

[15] UPI dan Direktorat PKLK Dikdas Kemendikbud (2015) Pedoman Khusus Pembelajaran Pendidikan Jasmani Adaptif bagi Peserta Didik Tunadaksa di SDLB. Bandung

[16] Wahyu, GG. 2009. Obesity Pada Anak. Yogyakarta: PT Bentang Pustaka.

[17] Widati, S., Murtadlo. 2007. Pendidikan Jasmani dan Olahraga Adaptif. Jakarta : Dirjen Dikti Departemen Pendidikan Nasional. 